\title{
SKUTECZNOŚĆ STOSOWANIA SOFT POWER REPUBLIKI KOREI W JAPONII I W CHINACH
}

\author{
THE EFFECTIVENESS OF SOFT POWER \\ OF THE REPUBLIC OF KOREA IN JAPAN AND CHINA
}

Julia Trzcińska*

\begin{abstract}
ABSTRAKT
Tekst jest próbą zwrócenia uwagi na problematykę korzystania z narzędzi miękkiej siły na przykładzie Korei Południowej i zjawiska zwanego Koreańską Falą oraz jego odbioru z państwach sąsiadujących - ChRL i Japonii. Opisując dwa konkretne konflikty z tymi państwami, artykuł stara się znaleźć odpowiedź na pytanie, gdzie są granice korzystania $\mathrm{z}$ potencjału soft power oraz jakie skutki negatywne może ono przynieść.
\end{abstract}

Słowa kluczowe: Korea Południowa; nastroje antykoreańskie; soft power; Koreńska Fala
The text is an attempt to draw attention to the problem of using soft power tools on the example of South Korea and the phenomenon known as the Korean Wave and its reception in the neighboring countries - the PRC, and Japan. By describing two specific conflicts with these countries, the article seeks to answer the question of where the limits of the use of soft power potential are and what negative effects it can bring.

Keywords: South Korea; anti-Korean sentiment; soft power; Korean Wave

* Uniwersytet Wrocławski, Wydział Nauk Społecznych. 
W literaturze z zakresu politologii i stosunków międzynarodowych coraz większego znaczenia nabiera pojęcie soft i smart power. W erze niemal nieograniczonego dostępu do internetu i informacji wizerunek, również państwa, stał się bardziej istotny niż kiedykolwiek, a decydenci zaczynają dostrzegać potencjał mediów społecznościowych w dwukierunkowym komunikowaniu politycznym - także na arenie międzynarodowej. Zagadnieniem interesują się przede wszystkim politolodzy badający potencjał państwa i możliwości wywierania wpływu, ale nie tylko. Soft power zajmują się także specjaliści od marketingu i brandingu na poziomie międzynarodowym, jak i aktorzy polityczni, którzy z większą lub mniejszą wprawą próbują stosować ich zalecenia, rozumiejąc, że pozycję państwa można bardzo skutecznie wzmacniać również za pomocą innych narzędzi niż naciski ekonomiczne i siła militarna.

Ostatnie lata charakteryzują się swego rodzaju fascynacją soft power i jej narzędziami. Państwa prześcigają się w pomysłach na promocję i próbach dotarcia do międzynarodowej opinii publicznej poprzez sport czy kulturę popularną, a jedyne, co wydaje się je ograniczać, to środki finansowe przeznaczane na ten cel. Brakuje jednak głębszej refleksji nad długofalowymi skutkami stosowania tych narzędzi oraz dobrze opisanych przykładów ze świata, które przedstawiałyby wszystkie ich aspekty. Najlepiej opisanym państwem, wykorzystującym swój potencjał w zakresie soft power, są oczywiście Stany Zjednoczone, jednak jako niemalże hegemon w zakresie produkcji kultury popularnej głównego nurtu, trudno przekładać ich doświadczenia na inny grunt i dokonywać porównań. Ciekawym przykładem skutecznego wykorzystania miękkiej siły do budowania własnej pozycji i rozpoznawalności na świecie jest natomiast Korea Południowa, której kultura popularna stanowi jeden z głównych z produktów eksportowych państwa i która dba o rolę middle power w regionie. Państwo to jako jedno z pierwszych musiało także zmierzyć się z negatywnymi skutkami stosowania narzędzi soft power i stanowi ciekawy przypadek nie tylko do analiz z zakresu komunikowania politycznego na poziomie międzynarodowym, ale także dla praktyków zajmujących się na co dzień planowaniem strategii promowania państwa.

Tekst będzie próbą znalezienia odpowiedzi na pytanie, gdzie leżą granice stosowania narzędzi soft power przez Republikę Korei ${ }^{1}$ na przykładzie reakcji w dwóch sąsiednich państwach - Chinach i Japonii. Nawiązując do tego, co

1 Republika Korei będzie w dalszej części tekstu nazywana także wymiennie Koreą lub Koreą Południową. 
zostało już napisane, pierwsza hipoteza badawcza zakłada, że tzw. Koreańska Fala może być uznawana za jeden $z$ ciekawszych i bardziej rozbudowanych przejawów wykorzystania narzędzi soft power, stanowiąc swego rodzaju przykład dla innych państw, druga natomiast mówi o tym, że współcześnie państwa stosują narzędzia miękkiej siły w sposób, który zdaje się nie przewidywać skutków długofalowych i może być odbierany jako imperializm kulturowy. Ze względu na ograniczone miejsce analiza skupiać się będzie na wykorzystaniu kultury popularnej, która zdaje się być najbardziej skuteczną częścią potencjału soft power Republiki Korei, chociaż oczywiście nie wyczerpuje to całości zagadnienia.

\section{KOREAŃSKA FALA - POCZATTKI I ROZWÓJ ZJAWISKA}

Pojęcie Koreańska Fala (kor. hallyu²) pojawiło się po raz pierwszy w 1998 roku w Chinach. Zostało one użyte przez dziennikarzy, którzy pisali o rosnącej popularności południowokoreańskiej kultury popularnej (Kim, 2013). Porównali ją wtedy do fali, ponieważ zdawała się „zalewać” chiński rynek, a ich obserwację z perspektywy czasu można uznać za wręcz proroczą, ponieważ Hallyu zaczęła podbijać rynki nie tylko azjatyckie, ale także te na Bliskim Wschodzie i w Ameryce Południowej, a później także w Ameryce Północnej oraz Europie. Obecnie temu zjawisku poświęcono już wiele prac badawczych i jest ono coraz lepiej opisane, ale warto wspomnieć o kilku cechach wyróżniających, które nie są powszechnie znane polskiemu czytelnikowi.

Rozwój Koreańskiej Fali dzieli się najczęściej na dwa etapy: pierwszy od lat 90. XX wieku (data ta jest związana z próbami przezwyciężenia kryzysu azjatyckiego z lat 1997/1998; Howard, 2013) do okolic roku 2000, drugi natomiast trwa do dziś. Pierwszy etap związany jest z tzw. zespołami I generacji oraz większą rolą dram (nazwa koreańskich telenowel), a także znaczącym zaangażowaniem rządu w promocję kultury poza granicami państwa. Zjawisko zauważalne było też przede wszystkim na rynkach azjatyckich. Drugi etap przyniósł wiele zmian - nie tylko związany jest on z większym zaangażowaniem samych fanów w dalszą, bardziej oddolną promocję południowokoreańskiej popkultury, ale także z większą rolą muzyki (tzw. K-Pop) oraz kolejnymi rynkami na świecie.

Wiele osób wskazuje, iż popularność zarówno koreańskich dram, jak i muzyki popularnej należy przypisać dbałości o szczegóły i dokładnemu planowaniu,

2 Koreańska Fala i Hallyu oznaczają to samo i będą w tekście używane zamiennie. 
które przekłada się na efekt końcowy. Mówi się o czterech elementach, które stanowią wyróżnik Koreańskiej Fali, a mianowicie o planowaniu, dystrybucji, zawartości i odbiorcach, z czego każdy jest dopracowany w najdrobniejszych szczegółach (Seo, 2012). Zarówno seriale, jak i zespoły muzyczne stanowią produkty najwyższej jakości, które już nie tylko śledzą najnowsze trendy na świecie, ale zaczynają je także wyznaczać. Członkowie południowokoreańskich zespołów potrafią oczywiście tańczyć i śpiewać, ale są również szkoleni w aktorstwie i językach obcych, co sprawia, że stają się artystami sprawdzającymi się na wielu polach (dobrze oddaje to angielskie słowo entertainer). Stanowi to jednocześnie jeden z głównych zarzutów, przede wszystkim przeciwko przemysłowi K-Popu, który odbierany jest jako fabryka muzyków pozbawionych własnego zdania, traktowanych jak lalki i jedynie wykonujących w identyczny sposób zlecone przez wytwórnię zadania. Wiele osób ma również z zasady zastrzeżenia co do traktowania kultury w kategoriach przemysłu, produktów i prostego kalkulowania zysków. Chociaż dyskusja w tym zakresie jest wciąż bardzo ożywiona, a wytwórnie zdają się zauważać, że jest to element, który często zniechęca potencjalnych odbiorców i pozwalają na coraz częstsze pokazywanie „ludzkiej twarzy” swoich podopiecznych, to niewątpliwie właśnie to długoterminowe planowanie i lata wymagających szkoleń w przypadku muzyki oraz duże nakłady finansowe przeznaczane na produkcję dram, a także pisanie scenariusza już w trakcie ich emisji wydają się głównymi aspektami stanowiącym o sukcesie Hallyu.

\section{ZNACZENIE POTENCJAŁU SOFT POWER DLA PAŃSTWA}

Wprowadzenie przywoływanego już kilkukrotnie pojęcia soft power przypisuje się J. Nye’owi i jego publikacji z 2004 roku (Nye, 2007). Chociaż niektórzy dowodzą używania miękkiej siły już w Starożytności (Laskai, 2013), to jednak rozwój zainteresowania tym pojęciem wiąże się $\mathrm{z}$ atakami terrorystycznymi w Stanach Zjednoczonych z 2001 roku, które pokazały rolę mediów w kształtowaniu międzynarodowej opinii (Ociepka, 2012). Według koncepcji amerykańskiego politologa siłę każdego państwa można podzielić na dwie składowe - hard power, czyli aspekty związane głównie z gospodarką i potencjałem militarnym, oraz soft power, czyli wynikająca między innymi z kultury, ale także polityki i ideologii, atrakcyjność oraz wiarygodność. B. Ociepka zwraca uwagę na to, że współcześnie to właśnie wiarygodność państwa stanowi podstawę w nawiązywaniu relacji międzynarodowych (2012). Większość teoretyków zgadza się także, iż dopiero 
umiejętne połączeniu obu wspomnianych składowych stanowi sukces w polityce zagranicznej i nazywane jest wtedy pojęciem smart power. W 2018 pojawiło się także zupełnie nowe pojęcie sharp power związane $\mathrm{z}$ wprowadzaniem pewnego zamętu informacyjnego i wykorzystywaniem nowoczesnych technologii do zakłócania polityki innych państw, czego najlepszym przykładem są działania Rosji i Chin (Nye, 2018). Sharp power nie służy jednak budowaniu pozytywnego wizerunku państwa stosującego jego narzędzia, a wręcz przeciwnie, w niektórych aspektach może stanowić nawet przeciwieństwo dla soft power.

Analizując zarówno potencjał twardej, jak i miękkiej siły Republiki Korei, łatwo można zauważyć, że chociaż państwo to znajduje się w grupie tzw. Azjatyckich Tygrysów i posiada bardzo rozwiniętą gospodarkę (dla opisu niezwykle szybkiego wzrostu gospodarczego w Korei Południowej mówi się nawet o „cudzie nad rzeką Han”), to sytuacja geopolityczna naznaczona jest przez sąsiedztwo Korei Północnej. Hard power Korei Południowej jest również relatywnie słaba w porównaniu do jej największych dwóch sąsiadów - Chińskiej Republiki Ludowej oraz Japonii. Specjaliści wskazują, że umiejętność funkcjonowania pomiędzy dwoma tak silnymi państwami jest zaletą Republiki Korei, ale niewątpliwie podkreśla to jej niższy status (Shim, Flamm, 2012). Problemem wydaje się także nieumiejętność odróżnienia Korei Południowej oraz produktów z niej pochodzących od innych państw azjatyckich, co świadczy o relatywnie słabej rozpoznawalności państwa jako marki (Shim, Flamm, 2012).

Przy braku możliwości wprowadzenia zmian w zakresie hard power, oczywistym jest, iż państwo powinno próbować maksymalizować potencjał wynikający z miękkiej siły. Republika Korei wykorzystuje także siłę sieciowości, starając się być ważnym „węzłem” w regionie poprzez budowanie więzi opartych na handlu i umowach gospodarczych oraz niekonfliktowym charakterze relacji (Rewizorski, 2016). Zarówno soft power, siłę sieci, jak i pojęcie państwa średniego rzędu wiąże się z tradycją neoliberalną w nauce o stosunkach międzynarodowych.

Specjaliści wskazują, że koreański soft power opiera się na dwóch aspektach, którymi są udane przejście do demokracji (Republika Korei w 2014 roku znalazła się na 21. miejscu rankingu Index Democracy The Economist Intelligence Unit w grupie pełnych demokracji) oraz kultura popularna (Lee, 2009). W zinstytucjonalizowanym podejściu do brandingu państwa, będącym częścią wzmacniania potencjału soft power, przełomowy wydaje się rok 2010, kiedy powstało Korea Public Diplomacy Forum (KPDF). Korea Południowa otworzyła się na dyplomację publiczną oraz promocję przez kulturę i obecnie posiada wiele organów odpowiedzialnych za ich prowadzenie - niestety często o zbyt podobnych 
kompetencjach, co może negatywnie wpływać na ich codzienne funkcjonowanie i skuteczność oraz spójność promowanego wizerunku państwa (Kim, 2012). Charakterystyczne dla południowokoreańskiego budowania marki państwa jest także nawiązywanie współpracy z sektorem biznesowym, na przykład firmami telekomunikacyjnymi, czy też wspomnianymi już wcześniej dużymi wytwórniami muzycznymi (Fuhr, 2016). Takie działania obarczone są jednak możliwością utożsamienia interesów prywatnych firm w zakresie kreowania brandingu państwa $\mathrm{z}$ interesem rządu, co wydaje się szczególnie niebezpieczne w sytuacji, w której organy administracyjne wyznaczone do tego zadania nie mają skoordynowanych działań $\mathrm{i}$ jasno podzielonych kompetencji.

W 2005 roku Samsung Economic Research Institute przedstawił raport, w którym zobrazowano wpływ Koreańskiej Fali na inne państwa w czterostopniowym procesie (Ko). Dokument ten przedstawia nie tylko dyplomatyczne korzyści, które Korea Południowa czerpie z popularności Hallyu, ale także wpływ zjawiska na gospodarkę państwa. Pierwszy etap charakteryzuje się „łapczywym” konsumowaniem produktów kulturalnych (na tym etapie ponad 10 lat temu znajdowały się Meksyk, Egipt oraz Rosja), na drugim etapie pojawia się podróżowanie do Korei Południowej (tutaj wymieniono Japonię, Hongkong i Tajwan), następnie potrzeba nabywania produktów związanych szerzej ze stylem życia, a nie tylko kulturą, np. telefony komórkowe czy inne technologie (Chiny, Wietnam). Ostatnim, niemalże idealnym stanem jest uznanie Korei za państwo warte naśladowania, co koreluje ze zdolnością kształtowania preferencji innych, o których mówi Nye, tłumacząc, czym jest soft power. Na tym etapie w 2005 nie znalazło się żadne państwo, ale badacze wskazali, że najbliżej znajdowała się Tajlandia, co było szczególnie widoczne wśród młodzieży (Kim, 2011).

Soft power najczęściej pozytywnie wpływa na zbliżanie państw, które najłatwiej jest zrozumieć i „polubić" poprzez poznawanie ich kultury, czego dowodzi również przedstawiony powyżej raport SERI, jednakże dość często zapomina się o przedstawieniu możliwych negatywnych skutków jej stosowania. Zbyt intensywna wymiana produktów kulturalnych, która przybiera w istocie formę jednokierunkowego „zalewu” jednego państwa przez drugie, z czasem spotka się z jakąś formą sprzeciwu obywateli państwa importującego - mniej lub bardziej ostrą, ale z reguły dość nieprzewidywalną. 


\section{RUCH ANTI-HALLYU W JAPONII}

Nastroje antykoreańskie w sferze kultury popularnej w Japonii wpisują się w szersze zjawisko, jakim jest ruch Anti-Korea w całej Azji. W Państwie Kwitnącej Wiśni przybrał on jednak najbardziej wyraźną, a nawet w pewien sposób zinstytucjonalizowaną formę. Zjawisko sprzeciwiania się popularyzacji południowokoreańskiej kultury nazywane jest Anti-Korean Wave lub Anti-Hallyu (jap. kenkanryu). Przyczyn japońskiej niechęci do Korei należy szukać w historii obu państw, które do tej pory nie uporały się z wieloma kwestiami spornymi. Do najbardziej żywych przykładów należą niewątpliwie konflikt o wyspy Dokdo/ Takeshima, okupacja Korei przez Japonię (która trwała od 1910 roku aż do końca II wojny światowej i zakończyła się podziałem półwyspu na dwa państwa) oraz kwestia tzw. comfort women, czyli niewolnic seksualnych wykorzystywanych przez japońskich żołnierzy, o których dramacie historia milczała do lat 90., a w ciągu dalszym rząd japoński nie spełnił wszystkich żądań Koreańczyków w tej sprawie, chociaż w 2015 roku osiągnięto pewne porozumienie. Po 2000 roku w Japonii obserwuje się także wzrost nastrojów prawicowych, co niewątpliwie przekłada się na stosunek do kultury innych krajów, szczególnie mając na uwadze, iż w latach 90. XX wieku to właśnie to państwo było prawdopodobnie największym eksporterem swojej kultury popularnej w regionie. Poniższy wykres obrazuje częstotliwość wyszukiwania haseł „K-Pop” i „J-Pop” od stycznia 2004 roku do marca 2018 roku. Widać na nim wyraźny wzrost zainteresowania muzyką południowokoreańską od okolic roku 2010 i sukcesywny spadek zainteresowania muzyką japońską (Wykres 1).

Podobne wyniki można uzyskać, wpisując zapytanie, które uwzględnia także poszukiwania dotyczące języków koreańskiego i japońskiego, których ilość praktycznie zrównała się pomimo początkowej olbrzymiej rozbieżności. Widać również, że zainteresowanie językiem koreańskim zaczęło rosnąć w podobnym czasie do wzrostu zainteresowania K-Popem, co może świadczyć o korelacji tych zjawisk, chociaż oczywiście nie można wykluczyć także innych czynników, wynikających chociażby z relacji biznesowych (Wykres 2).

Zrozumiałe jest więc, iż Japończycy mogli odczuć utratę swojej pozycji na rzecz Korei Południowej i odbierać to państwo w kategoriach konkurencji, szczególnie w kontekście wspomnianych już konfliktów historyczno-politycznych.

W 2014 roku przeprowadzono badania, które pokazały, że aż 66,4\% Japończyków ma negatywny stosunek do Korei, co było najwyższym wynikiem od 1975 , kiedy po raz pierwszy zadano to pytanie (Kang, 2014). Ich niezadowolenie, 


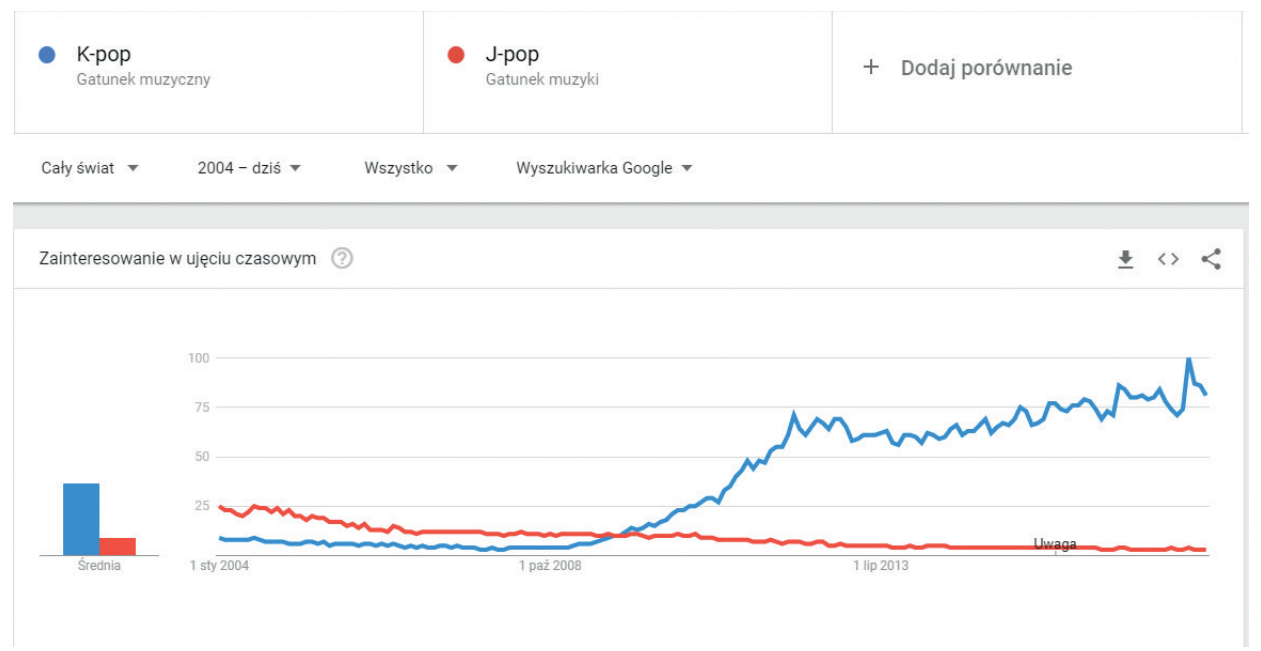

Wykres 1. Wyszukiwanie haseł "K-Pop" i "J-Pop" w wyszukiwarce Google (01.2014-03.2018)

Źródło: Google Trends.

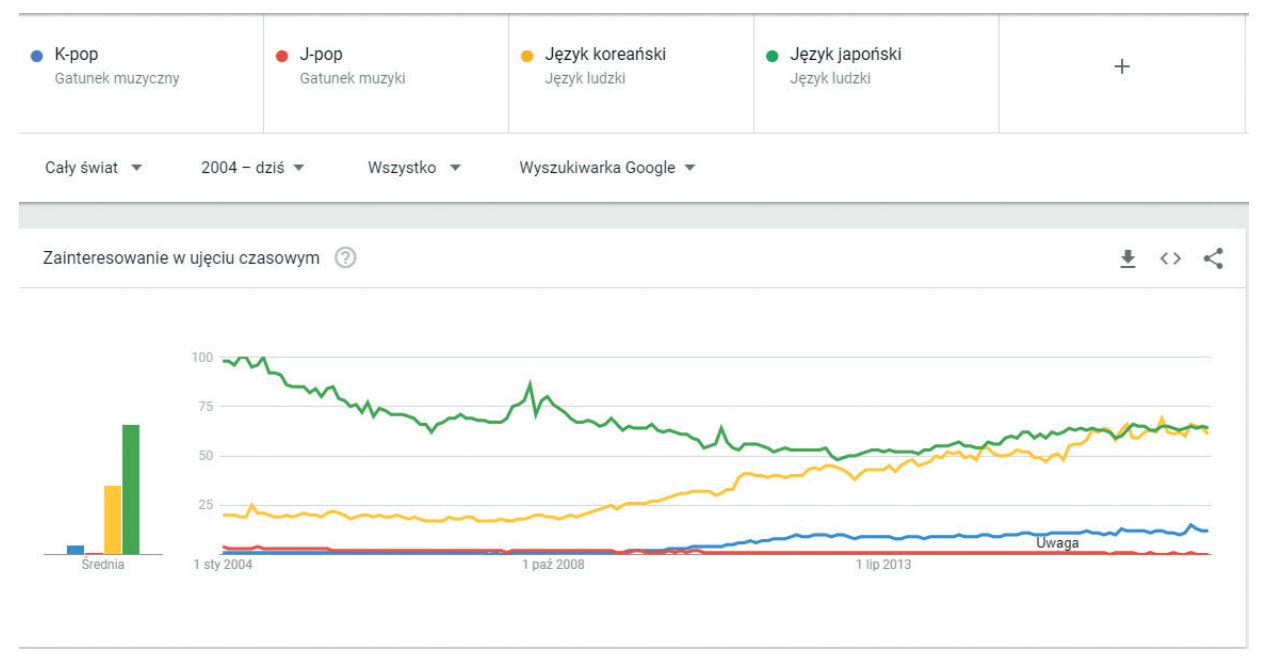

Wykres 2. Wyszukiwanie haseł "K-Pop”, "język koreański”, "język japoński” i "J-Pop” w wyszukiwarce Google (01.2014-03.2018)

Źródło: Google Trends. 
czy wręcz sprzeciw wobec produktów kulturalnych pochodzących z sąsiedniego państwa związany jest także z grupą Zaitokukai, która jest prawicową grupą populistyczną, budującą swoją tożsamość na nienawiści do Koreańczyków Zainichi - mniejszości mieszkającej w Japonii. Jest to jedna z wielu grup, która powstała wraz ze wzrostem poparcia dla grup nacjonalistycznych, także tych skrajnych, po 2000 roku (Mikalajunaite, 2015), jednak jako jedna z niewielu, ze względu na swoją radykalność, jest postrzegana jako zagrożenie dla porządku publicznego. Ze względu na ich działalność Japonia została nawet ostrzeżona przez Organizację Narodów Zjednoczonych, że powinna ograniczyć mowę nienawiści i zakończyć wszystkie antykoreańskie działania, które mają miejsce na jej terytorium. To właśnie grupa Zaitokukai ostrzegała także, że kultura koreańska jest „nieczysta”. Wielu Japończyków postrzega ją jedynie jako narzędzie propagandy i zarzuca Korei Południowej tzw. imperializm kulturowy, co doprowadziło już kilkukrotnie do protestów na ulicach inspirowanych głównie $\mathrm{z}$ inicjatywy wspomnianej grupy (Japan's right-wing...). W internecie pojawiały się także deklaracje o zaprzestaniu oglądania niektórych stacji telewizyjnych, które nadawały programy koreańskie, mające rzekomo ogłupiać publiczność swoim niskim poziomem (Hundreds of Japanese Protest...).

W Japonii powstają również mniej agresywne niż protesty czy bezpośrednie ataki produkty kulturalne mające stanowić odpowiedź na te z Korei oraz wykorzystujące przystępną formę rozrywki w celu wywoływania określonych postaw przeciwko temu sąsiedniemu państwu. Najbardziej znanym przykładem jest niewątpliwie manga Kenkanryu („Hating Korean Wave”), której sam tytuł nie pozostawia wątpliwości co do jej zawartości. Komiks przedstawia Koreańczyków w bardzo stereotypowy sposób jako osoby głośne i kłótliwe, często o zniekształconych rysach, przeciwstawiając im Japończyków, u których podkreśla się duże oczy, małe nosy oraz regularne rysy twarzy. Cała akcja rozgrywa się podczas Mistrzostw Świata w Piłce Nożnej organizowanych przez Japonię i Koreę w 2002 roku i sugeruje, że Koreańczycy wykorzystali całą imprezę do swoich własnych celów - często korzystając z nielegalnych metod. Niektórzy uważają nawet, iż to właśnie wspólna organizacja Mundialu pokazała Japonii, że w wielu aspektach Korea Południowa jest już bardziej rozwinięta od ich własnego państwa. Manga sprzedała się jako bestseller w 2005 roku i nie tylko nie spotkała się ze sprzeciwem ze strony polityków, ale niektórzy nawet uznali, że rzetelnie oddaje stosunki między państwami (Onishi, 2005a). W 2011 roku powstała kolejna manga skierowana przeciwko koreańskiej muzyce popularnej. Komiks zatytułowany „The Investigation of the Fabricated Hallyu Boom” sugerował, że 
koreańskie zespoły muzyczne tak naprawdę świadczą usługi seksualne wysoko postawionym mężczyznom w celu osiągnięcia sukcesu (manga przedstawia dwa prawdziwe girlsbandy - Girls' Generation i KARA), a cały przemysł K-Popu został stworzony przez południowokoreański rząd między innymi w celu zepsucia praworządnego społeczeństwa Japonii (Mikalajunaite, 2015). Zgoda na takie przedstawianie Koreańczyków szybko zaowocowała dopatrywaniem się przejawów ich barbarzyństwa w niemal każdej sytuacji. Przykładem może być reklama błyskawicznego ramen, pokazująca piosenkarkę jedzącą makaron z pokrywki garnka, co służy schłodzeniu gorącego dania i jest bardzo popularnym sposobem jego jedzenia w Korei; wywołała ona dyskusję o rzekomym niższym stopniu rozwoju obywateli sąsiedniego kraju (Kim, 2012). Na siłę wskazuje się także, że Korea próbuje dyskredytować Japonię, czego przejawem było doszukiwanie się nawiązań do elektrowni w Fukushimie i flagi państwa w teledysku 2NE1 „I Hate You”.

Konsekwencją obecnej sytuacji jest rosnąca niechęć między Japonią i Koreą Południową. Warto zaznaczyć, że rynek japoński jest dla Koreańskiej Fali szczególnie ważny, ponieważ japońscy fani, gdy już zostaną do czegoś przekonani, są jednymi z najbardziej oddanych, ale niestety jednocześnie trudno przewidzieć wybuch kolejnych nastrój antykoreańskich. Dla odbiorców japońskich oczywiste jest, że zespoły, które chcą odnieść sukces w ich kraju, będą nagrywać piosenki także po japońsku i regularnie koncertować w japońskich miastach, z czego wytwórnie zdają sobie sprawę i co robią. Przykładem tego, jak daleko kwestie polityczne związane są z kulturą $\mathrm{w}$ relacjach japońsko-koreańskich może być piosenka „Gangnam Style" rapera Psy, która została źle przyjęta w Japonii jako prawdopodobnie jednym z niewielu krajów na świecie - muzyk nie tylko nie zamierzał uczyć się japońskich zwrotów ani koncertować w tym państwie, ale wydanie utworu zbiegło się także w czasie z powrotem kwestii wysp Dokdo/ Takeshima i zaostrzeniem relacji. Warto przypomnieć także, iż oficjalnie rząd w Tokio podaje Republikę Korei jako swojego najważniejszego partnera w relacjach międzynarodowych, wskazując na podobne cele strategiczne. Na swój sposób uspokajająco powinien działać także ranking The Soft Power 30 (2017), w którym Japonia zajmuje szóste miejsce, wyprzedzając Koreę Południową zajmującą dopiero 25. lokatę, bowiem zestawienie uwzględnia wszystkie składowe potencjału soft power - nie tylko kulturę popularną. Interesujące zmiany mogą zajść także w nadchodzących latach, ponieważ coraz częściej zwraca się uwagę na fakt, iż młodzi Japończycy mieli więcej kontaktu z południowokoreańską popkulturą niż problemami natury politycznej lub historycznej, a ich stosunek 
do sąsiedniego państwa jest dużo bardziej pozytywny niż pokolenia ich rodziców (Lee, 2018).

\section{KONFLIKT Z CHINAMI Z 2016 I 2017 ROKU}

Odbiór Koreańskiej Fali w Chinach od samego początku wyglądał inaczej niż w Japonii (Lee, 2011). Chińczycy wypowiadali się o produktach koreańskich bardzo pozytywnie i chętnie importowali je do swojego kraju, a później nawet naśladowali. Media podawały nawet przypadki, w których państwowa administracja musiała wydawać ostrzeżenia przed nadmiernym zaangażowaniem, na przykład w oglądanie dram, a wszystko to po przypadku dziewczyny, u której zdiagnozowano ostrą jaskrę po maratonie oglądania niezwykle popularnego serialu „Descendants of the Sun” (Premack, 2017). Pomimo jednostronnego zalewu chińskiego rynku przez południowokoreańską popkulturę obywatele Państwa Środka zdawali się nie przejmować nierównością kontaktów. Przeciwstawianie się Hallyu wyszło odgórnie ze strony rządu jako reakcja na sytuację polityczną w regionie.

Początki tego kryzysu sięgają przełomu lipca i sierpnia 2016 roku, kiedy to Republika Korei podjęła decyzję o zamontowaniu tarczy antyrakietowej THAAD (Terminal High Altitude Area Defense) na swoim terytorium. Tarcza miała stanowić przeciwwagę dla działań Korei Północnej, jednakże ChRL bardzo ostro wypowiedziała się o pomyśle, uznając, że jest ona potencjalnie groźna dla bezpieczeństwa samych Chin i zażądała wycofania się z projektu (Kruczkowska, 2017). W miarę upływu czasu, gdy jasne się stało, że Korea Południowa nie zamierza tego uczynić, zaczęto stosować nieoficjalne sankcje w sektorze produktów kulturalnych.

Oficjalnie Pekin zaprzeczył stosowaniu takich środków, ale w praktyce artyści południowokoreańscy nie dostawali pozwoleń na występowanie w Chinach, a produkcje koreańskie lub chociażby takie, w których występowali także koreańscy aktorzy, nie dostawały zezwoleń na rozpowszechnianie na terytorium Państwa Środka, przez co wiele osób zaczynało wycofywać się z łączonych produkcji. Wycinano aktorów z reklam i anulowano ich kontrakty, a w grudniu 2016 roku 19 firm koreańskich dostało zakaz eksportu swoich produktów do Chin (Jozuka, Han, 2017). Sankcje dosięgły nawet muzyki klasycznej i planowanych z dwuletnim wyprzedzeniem koncertów. Ofiarą padła także grupa Lotte - jedna z największych południowokoreańskich korporacji, która sprzedała swój teren 
wojsku pod budowę tarczy - ich sklepy w Chinach musiały liczyć się z bardzo szczegółowymi kontrolami, których w większości nie przechodziły i były zamykane. W kraju natomiast musieli liczyć się ze stratami, jakie przyniosła ich sieć sklepów wolnocłowych (Lotte Duty Free), w której kupują głównie Chińczycy (Premack, 2017). Warto także pamiętać, iż Korea Południowa jest trzecim partnerem ekonomicznym Chin, natomiast Chiny są pierwszym partnerem dla Korei, a rynek Hallyu szacuje się w tym państwie na około 1 miliarda dolarów (Jozuka, Han, 2017).

Cała sytuacja odbiła się szerokim echem w obu państwach, chociaż ze względu na zaprzeczenie podjęcia jakichkolwiek oficjalnych działań trudno było przedsięwziąć konkretne kroki przeciwdziałające. W Chinach dość szybko niektórzy obywatele utożsamili się z linią przyjętą przez elity i rozpoczęli także oddolne działania zmierzające do sabotowania popularności Korei Południowej, natomiast w samej Korei pojawiały się pojedyncze, ale ostre głosy, które oskarżały ChRL o brak interwencji w Korei Północnej, która to miałaby stanowić znacznie lepsze rozwiązanie niż THAAD, a także nawiązania do Rewolucji Kulturalnej (Grow Up, China). Wiele osób uważało także, że kwestia tarczy była po prostu wymówką dla zatrzymania rozwoju Koreańskiej Fali lub też dlatego, że Chiny musiały jakoś zareagować na THAAD, a uderzenie w miękką siłę Republiki Korei było zdecydowanie łagodniejszym rozwiązaniem niż groźby odwołujące się do kwestii gospodarczo-militarnych.

Kryzys przyniósł przede wszystkim ogromne straty w turystyce i handlu oraz ochłodzenie relacji pomiędzy Chinami i Koreą Południową. Badania przeprowadzone przez BBC World Service pokazują wyraźnie ogromną zmianę w podejściu Chińczyków do ich sąsiadów. W 2010 roku jedynie 20\% ankietowanych w tym państwie postrzegało wypływ Korei Południowej jako negatywny (BBC, 2010), natomiast w badaniach przeprowadzonych w 2017 roku było to już 71\% (BBC, 2017). To także Chińczycy zdecydowanie najrzadziej wśród wszystkich respondentów nie umieli określić wpływu Korei Południowej w żaden sposób, co pokazuje, że większość obywateli tego państwa ma wyrobione zdanie na temat sąsiada, a sama Korea zapewne często pojawia się w mediach jako temat rozmów. Pomimo wielu zdecydowanie negatywnych skutków można odnaleźć jednak pewne pozytywne aspekty opisanego konfliktu. Zmusiło to Koreańczyków do otwarcia się na inne regiony, np. Stany Zjednoczone (Liu, 2017) i Azję Południową, przygotowania nowych strategii biznesowych oraz większej uważności w kwestii skutków Koreańskiej Fali. Pewne ocieplenie w stosunkach koreańsko-chińskich nastąpiło po majowych wyborach prezydenckich, w których wygrał 
Moon Jaein, opowiadający się przeciwko tarczy na terytorium Korei Południowej. 31 października 2017 roku udało się osiągnąć porozumienie i zakończyć trwające ponad rok napięcie dyplomatyczne pomiędzy ChRL i Koreą Południową (S. Korea, China move...), co wydaje się szczególnie ważne w kontekście nadchodzących igrzysk olimpijskich w mieście Pyeongchang.

\section{ZAKOŃCZENIE}

Potencjał Koreańskiej Fali jest niezaprzeczalnie duży. Zjawisko to ma ogromne znaczenie dla budowania wizerunku państwa i kształtowania jego odbioru na świecie. Dzięki niemu udało się chociażby zmienić obraz społeczeństwa koreańskiego $\mathrm{z}$ feudalnego, zorientowanego na mężczyzn i zamkniętego, na rozwinięte, otwarte i demokratyczne (Onishi, 2005b). Prawdopodobnie jest to również wynik faktycznych zmian w samej Korei Południowej, a nie tylko promowania jej określonego wizerunku na świecie, ale za sukces należy uznać odnotowanie tego przez międzynarodową opinię publiczną. Hallyu miała także duży wpływ na poprawę relacji Republiki Korei z sąsiednimi państwami - Chinami i Japonią. Przez kilka dekad po okupacji w Korei funkcjonował zakaz rozpowszechniania kultury japońskiej, który skutkował brakiem japońskich filmów i seriali w kinach i telewizji oraz sprowadzaniem mang $\mathrm{z}$ Japonii i wydawaniem ich na nowo przez firmy koreańskie pod zmienionymi tytułami i pseudonimami autorów - dzięki ogólnie pozytywnej reakcji Japończyków na Hallyu, Korea Południowa zdecydowała się znieść zakaz pod koniec lat 90 . XX wieku i pozwolić na bardziej zrównoważoną wymianę produktów kulturalnych.

Jednakże, jak przedstawiono powyżej na przykładzie popkultury, stosowanie soft power ma swoje ograniczenia i chociaż są one słabiej opisane niż pozytywne skutki, to należy o nich pamiętać. Głównym zarzutem, który może się pojawić w przypadku intensywnego promowania własnej kultury, to stosowanie imperializmu kulturowego - Korea Południowa została o to oskarżona zarówno przez Chiny, jak i Japonię. Ponadto warto zauważyć, że bezpośredni negatywny odbiór rzadko obserwowany jest u całości społeczeństwa. W Japonii były to głównie grupy nacjonalistyczne, w Chinach natomiast nieoficjalne działania rządu - w obu przypadkach bardzo szybko zaczęły one jednak oddziaływać na opinię publiczną poprzez odpowiednie przedstawienie sprawy w mediach i uramowienie.

Oba przypadki pokazują, jak ważna dla polityki może być kultura popularna i jak istotne jest rozważne i długofalowe planowanie w tej sferze. Warto 
także podkreślić, że relacje między polityką i kulturą popularną są dwustronne, co oprócz opisanych przypadków obrazują także reakcje Tajwanu na Hallyu. Obywatele tego państwa bardzo chętnie oglądają południowokoreańskie seriale, nie kupują jednak produktów koreańskich na taką skalę, jakby się można było tego spodziewać. Wynika to nie tylko z gospodarczej rywalizacji pomiędzy tymi nastawionymi na eksport państwami, ale także z subiektywnego poczucia zdradzenia Tajwanu przez Koreę, kiedy to w 1992 roku państwo to, postrzegane do tej pory jako sojusznik w walce $\mathrm{z}$ komunizmem, postawiło na relacje gospodarcze z Chinami (Taiwan Embraces Korean Culture) w celu budowania swojej pozycji jako państwa średniego rzędu.

Koreańska Fala ma potencjał, żeby stanowić pewnego rodzaju przeciwwagę dla kultury amerykańskiej, szczególnie w regionie Azji, gdzie już teraz często jest bardziej popularna. Azjaci chętniej sięgają po produkty, które są bliżej reprezentowanych przez nich wartości, a także, które są po prostu mniej odmiennie wizualnie (Kim, 2007). Jednakże, chcąc dalej się rozwijać w tym aspekcie, Korea Południowa - oprócz kwestii technicznych i czysto biznesowo-marketingowych - musi brać pod uwagę także możliwe negatywne reakcje i starać się, by kultura popularna, którą eksportuje, nie była tak łatwym obiektem ataku. Chociaż trudno jest przewidzieć wybuchy nastrojów antykoreańskich, które z reguły są odpowiedzią na zaostrzenie relacji wynikające ze sfery polityki, to z pewnością można osłabić chęć jej atakowania, stosując bardziej zrównoważoną wymianę kultury oraz stawiając na dialog i odbierając tym samym przeciwnikom argument stosowania przez Koreę Południową imperializmu kulturowego.

\section{BIBLIOGRAFIA:}

BBC (2010). Global Views of United States Improve While Other Countries Decline. BBC World Service Poll Report.

BBC (2017). Sharp Drop in World Views of US, UK: Global Poll. BBC World Service Poll Report.

Fuhr, M. (2016), Globalization and Popular Music in South Korea. Sounding Out K-Pop. New York and London.

Grow Up, China. The Korea Times. Pobrane z: http://www.koreatimes.co.kr/www/ opinion/2017/ 03/202_225025.html.

Howard, K. (2013). The Foundations Of Hallyu - K-Pop's Coming Of Age. Seoul: Korea University.

Hundreds of Japanese Protest Against Korean Wave. The Chosun Ilbo. Pobrane z: http:// english.chosun.com/site/data/html_dir/2011/08/09/2011080901004.html. 
Japan's right-wing hold rallies vs. Korean pop culture, The Dong-A Ilbo. Pobrane z: http:// english.donga.com/List/3/all/26/401888/1.

Jozuka, E., Han, S. (2017). Why South Korean companies, entertainers are getting cold shoulder in China. Pobrane z: http://edition.cnn.com/2017/02/23/asia/south-korea-china-thaadretaliation/index.html.

Kang, T. (2014). Japan's Growing Anti-Korean Sentiment. Pobrane z: http://thediplomat. com/2014/12/japans-growing-anti-korea-sentiment.

Kim, E. (2012). Most Ridiculous Anti-Hallyu Movements in Japan. Pobrane z: https:// www. soompi.com/2012/05/13/most-ridiculous-antihallyu-movements-in-japan.

Kim, J. (2007). Rethinking Media Flow Under Globalisation: Rising Korean Wave and Korean TV and Film Policy Since 1980s. University of Warwick.

Kim, R. (2011). Searchers and Planners: South Korea's Two Approaches to Nation Branding,W: US-Korea 2010 Yearbook. Washington: U.S.-Korea Institute at SAIS. Kim, T. (2012). Paradigm Shift in Diplomacy: A Conceptual Model for Korea's "New Public Diplomacy". Korea Observer, 43(4).

Kim, Y. (2013). Korean Media in a Digital Cosmopolitan World. W: K. Youna (red.). The Korean Wave. Korean media go global. New York.

Ko, J. (2005). How to Commercialize "Korean Wave". Samsung Economic Research Institute, Management Report. Pobrane z: http://www.seriworld.org/ 01/wldContV.html?mn=B\&mncd $=0101 \& \mathrm{key}=20050607037000 \&$ sectno $=\&$ cont_type =C. Kruczkowska, M. (2017). Amerykanie zaczęli rozmieszczanie tarczy antyrakietowej w Korei Południowej. Pobrane z: http://wyborcza.pl/7,75399,21699713,amerykanie-zaczeli-rozmieszczanie-tarczy-antyrakietowej-w-korei.html\#BoxGWImg.

Laskai, L.C. (2013). Soft Power or Ancient Wisdom? Pobrane z: http://thediplomat. com/2013/08/soft-power-or-ancient-wisdom.

Lee, D. (2018). Korean Wave Slops Back into Japanese Affections. The Chosun Ilbo. Pobrane Z: http://english.chosun.com/site/data/html_dir/2018/01/23/2018012301437.html

Lee, G. (2009). A Theory of Soft Power and South Korean Soft Power Strategy. Korean Journal of Defense Analysis, 21(2), 12.

Lee, S. (2011). The Korean Wave: The Seoul of Asia. The Elon Journal of Undergraduate Research in Communications, 2(1).

Liu, M. (2017). Locked out of China, South Korea's K-pop Stars are Heading to the US. Pobrane z: http://edition.cnn.com/2017/05/21/asia/shinee-kpop-bands-touring-us/index.html.

Mikalajunaite, U. (2015). Anti-Korean Wave and Far-Right Nationalist Wing in Japan. Leiden University.

Nye, J.S. (2007). Soft Power. Jak osiagnąć sukces w polityce światowej. Warszawa: Wydawnictwa Akademickie i Profesjonalne.

Nye, J.S. (2018). How Sharp Power Threatens Soft Power. The Right and Wrong Ways to Respond to Authoritarian Influence. Foreign Affairs. Pobrane z: https://www.foreignaffairs.com/articles/china/2018-01-24/how-sharp-power-threatens-soft-power.

Ociepka, B. (2012). Nowa dyplomacja publiczna - perspektywa teorii stosunków międzynarodowych i komunikowania politycznego. Przegląd Strategiczny, 2012(1). 
Onishi, N. (2005a). Roll Over, Godzilla: Korea Rules. Pobrane z: http://www.nytimes. com /2005/06/28/world/asia/roll-over-godzilla-korea-rules.html.

Onishi, N. (2005b). Ugly Images of Asian Rivals Become Best Sellers in Japan. Pobrane z: http://www.nytimes.com/2005/11/19/world/asia/ugly-images-of-asian-rivalsbecome-best-sellers-in-japan.html.

Premack, R. (2017). A Row With China Over U.S. Missiles Is Devastating South Korea's Tourism Industry. Time. Pobrane z: http://time.com/4734066/south-korea-tourism-china-thaad/.

Rewizorski, M. (2016). Przejawy koncepcji liberalnej polityce zagranicznej Republiki Korei, W: A. Wróbel, E. Haliżak, R. Ożarowski (red.). Liberalizm \& Neoliberalizm w badaniu polityki zagranicznej państwa i gospodarki światowej. Warszawa.

S. Korea, China Move to Put Year-Long THAAD Feud Behind Them, Yonhap News Agency. Pobrane z: http://english.yonhapnews.co.kr/focus/2017/10/31/66/1700000000AEN20171031008200315F.html.

Seo, M. (2012). K-Pop's Global Success and Implications. W: Samsung Economic Institute Research Brief, Seoul.

Shim, D., Flamm P. (2012). Rising South Korea: A Minor Player or a Regional Power. German Institute of Global and Area Studies Working Papers, 200(2012).

Taiwan Embraces Korean Culture, But Not Goods. The Chosun Ilbo. Pobrane z: http:// english.chosun.com/site/data/html_dir/2009/07/06/2009070600608.html.

The Soft Power 30. A Global Ranking of Soft Power (2017). Pobrane z: https://softpower30.com/wp-content/uploads/2017/07/The-Soft-Power-30-Report-2017-Web-1. pdf. 